\title{
Engaging Differences in Chosŏn Korea: A Post-Ming Context
}

Jeong-il Lee*

\section{The Use of Confucianism in a Time of Crisis}

For more than half a century, modern Korean scholarship has sought to counter the colonialist narrative of Japanese historiography by tying certain changes in pre-modern Korea to an orientation towards 'the modern.' The Chosŏn dynasty (1392-1910) was regarded as the endpoint of premodern Korea and the beginning of modern Korea. ${ }^{1}$ In intellectual history, this supposition has reinforced such themes as the discovery of protonational identity, new streams of thought against or beyond Confucianism, and the growth of popular culture. This paradigm, however, places a premium on certain intellectuals whom Korean historians expect to better represent a self-motivated consciousness towards modern Korea. Some scholars underscore the intellectual strands of marginalized elite groups in

* Research Fellow, Northeast Asian History Foundation.

1 More specifically, the Internal Development Theory (naejaejŏk palchŏnnon 內在的 發展論) characterizes late Chosŏn as the Dissolution Period (haech'egi 解體期) or the Transition Period (chŏnhwan'gi 轉換期) to enhance the empirical and theoretical sophistication of the development discourse and accommodate the space of particularity in Korean history. See Han'guk chungsesahoe haech'egi ŭi chemunje (I) (II), ed. Kündaesa yŏn'guhoe (Seoul: Hanul, 1987); Han'guksa chŏnhwan'gi ŭi munjedŭl, ed. Han'guksa yŏn'guhoe (Seoul: Chisiksanŏpsa, 1993); Chosŏn chŏngch 'isa (I) (II), ed. Han'guk yŏksa yŏn'guhoe (Seoul: Ch'ŏng'nyŏnsa, 1990). 
positivist, reformist, and pragmatist accounts as opposed to the obsession of the ruling elites to politico-cultural toadyism centering on imperial China. $^{2}$ On the other hand, other scholars maintain that it is the intellectuals who remained close to the political center and developed progressive scholarship in response to the historical changes of the time. ${ }^{3}$ That is to say, in spite of differences in emphasis the attention of scholars on both sides to the presence or absence of new epistemological alternative/breakthroughs reveals a dichotomist framework in tandem with a teleological, retrospective, and prescriptive mode of interpretation.

Meanwhile, moving beyond these dichotomist explanations, some scholars recently have shed fresh light on a close linkage between the reality of power relations, including both domestic politics and geopolitics, and the scholarly (re-)production of knowledge, based mostly on Chosŏn Confucianism, especially after the fall of Ming China (13681644). ${ }^{4}$ To chart a more specific topology of this association of politics and academics, they also search for the ongoing connection between the deep-seated structural context of historical Chosonn and the ideational push, in defense of individual morality and dynastic legitimacy, by

2 Han'guk minjoksasangsa taegye IV ed. Yi Sŏn'gŭn (Seoul: Hyŏngsŏlch'ulp'ansa, 1978), 11-90 and 77-80; Kim T'aeyŏng, "Chujahak segyegwan kwa chosŏn sŏngnihag ŭi chuch'eŭisik," Taedongmunhwayŏn'gu 37 (December 2000): 224-5 and pp. 97-139.

3 Particularly, this reverse opinion presents the self-reliant civilization discourse of the power elites as a meaningful departure from the Sino-centric worldview and a new chapter of national subjectivity. See Chŏng Okcha, Chosŏnhugi chunghwasasang yŏn'gu (Seoul: Ilchisa, 1998), 11-25 and 286-278; Chi Tuhwan, Chosŏnsidae sasangsa ŭi chaejomyŏng (Seoul: Yŏksamunhwa, 1998), 270 and 283-284.

4 Cho Sŏngsan, “Yŏn'am gŭrŭp ŭi ijŏk nonŭi wa ch'unch'u," Han'guksayŏn'gu 172 (December 2016); , "Hong Taeyong ŭi igisimsŏngnon kwa chiyŏkch'unch'u nonŭi," Yǒksa wa Tanmon 78 (April 2016); Kim Ho, "Chosŏnhugi hwairon chaego," Han'guksayŏn'gu 162 (September 2013); Cho Sŏngsan, Chosŏnhugi nangnon' 'gye hakp' 'ung ŭi hyŏngsŏng kwa chŏn'gae (Seoul: Chisiksanŏpsa, 2007). 
Chosŏn elites. ${ }^{5}$ In the process, what should not go unnoticed is the agency of the intellectual community of Chosŏn, which appropriated Confucian terms and concepts to the furtherance of their maneuvering regarding various social, political, and cultural agendas, viz. the application of Confucianism to the reality of Chosŏn.

More importantly, in my estimation, the new research helps to lend some more precise contours to the intellectual history of Chosŏn by way of featuring a persistent entanglement of epistemological conflicts and compromises in accordance with domestic and external contingencies. This perspective avoids the danger of fossilizing various intellectual practices into an ahistorical modern frontage and forcing their complexities into a binary with a set barometer. ${ }^{6}$ In the process, it signifies the intense dialogue between Confucianism and power relations, inseparable from the cultural security of Chosŏn under the Qing-centered regional order, thereby averting any naïve presumption of modern consciousness or any simplistic overestimation of the speculative mechanism of Chosŏn Confucianism.

The fulcrum of this article is also the way the Chosŏn elites took advantage of Confucianism in order to treat such critical external elements

5 The common term for the ruling class and leadership of Chosŏn was $\mathrm{Sa}$ 土 or yangban 兩班. They 'stood out as the utmost producers of the official ideology, especially translating kangsang 綱常 (timeless order), centering on filial piety, loyalty and the social hierarchy of Confucianism, into the conventional status system and legitimizing their hegemonic position in Chosŏn. At the same time, they exerted continuing influence on public opinion by way of various Confucian mechanisms of checks and balances at the political center.' For more reference, see Joseph Jeong-il Lee: "Patterning a Chosŏn-focused Discourse in Yi I's Understanding of Li," Journal of Asian History 46, no. 1 (August 2012): 37-38.

6 Fernand Braudel warns against the problems of excessive theoretization that "have been frozen in all their simplicity by being given the status of laws, of a preordained and automatic explanation, valid in all places and to any society.' Fernand Braudel, On History, trans. Sarah Matthews (Chicago, IL: The University of Chicago Press, 1980), 51. 
as the rise of Qing China (1644-1912) in the late seventeenth century. More specifically, I focus on the vital intersection of the debate on human nature during the Ming-Qing transition period and the pragmatist counterstrategy concerning the Qing hegemony. What is to be placed as a prerequisite for this purpose, then, is the vantage point in which to deem their seemingly cerebral debate as a form of discursive practice which was in no way detached from the statecraft and national security of Chosŏn. In fact, Herman Ooms points out the significance of intellectual attention to human nature because, "it constitutes an important link between metaphysics and ethics, and can, therefore, provide insights into the relationship between theory or worldview and actual practice. People implicitly act out notions of human nature, or explicitly appeal to them to justify or criticize certain practices."7 Along this line, he resituates the Tokugawa Confucian debate on human nature at the level of power practice under the Bakufu system.

In the case of Chosorn, the issue of how to redefine the differences in human nature during the time had a direct bearing on the complexity of geopolitics that constituted certain long-term historical processes of triangular interaction between Choson, the Jurchens, and the Ming. To begin with, the court and ruling elites of Chosŏn prided themselves on their statecraft and culture almost in parallel with those of the Ming and far above those of the Jurchens and the Mongols. Diplomatically, in the violent face of the Jurchens and the Mongols, Chosorn and the Ming maintained a cooperative relationship with each other. In particular, the Jurchen question was one of the top priorities between Chosonn and the Ming on the grounds that the Jurchens had been encroaching on the northwestern borderline of Chosonn and the northeastern frontier of the

7 See Herman Ooms, "Human Nature: Singular (China) and Plural (Japan)?," in Rethinking Confucianism: Past and Present In China, Japan, Korea, And Vietnam, eds. Benjamin A. Elman, John B. Duncan, and Herman Ooms (Los Angeles: UCLA Asian Institute, 2002), 95-115. 


\section{Ming. ${ }^{8}$}

The geopolitical upheavals of the seventeenth century, including the Manchu Invasions of Chosŏn in 1627 and 1636, the rise of Qing China (1636-1912) in 1636 and the fall of the Ming in 1644, dramatically reshaped the regional order of Northeast Asia. After the Jurchen attack in 1627, Chosŏn had to accept a higher status of the Jurchens as Big Brother; in 1636, King Injo (仁祖 r. 1623-1649) returned from the besieged the Namhan Mountain Fortress and kowtowed, kneeling three times and bowing his head down to the ground nine times, to Hong Taiji (r. 1636-1643), an unprecedented event in the history of Chosorn. ${ }^{9}$ Since that unwilling surrender, Chosŏn-Jurchen relations turned into a hierarchical structure that granted the Jurchens, or the emerging Qing, supreme ascendency and renounced Ming hegemony.

However, the long-standing past of the Jurchens as uncivilized subordinates and the still fresh memory of the humiliating defeat by these barbarians was never diminished in Chosŏn. Although accepting the hegemony of the Qing in diplomacy, the Chosorn court and ruling elites displayed an inner dimension of competence, based upon morality and scholarship, over the Qing. So, regardless of the geopolitical status quo, they started establishing an ideological frontline intent on rearming themselves with Confucianism and dichotomizing civilization and barbarity in an anti-Qing campaign. This double stance to the post-Ming change stood

8 Despite the façade of amity and collaboration, the two states kept the principle of checks and balances in realpolitik. The Ming stayed vigilant in a possible affiliation between Chosŏn and the Jurchens while Chosŏn was not always comfortable with the Ming's request for military cooperation against some powerful Jurchen tribes in the fifteenth and sixteenth centuries. Lee Kyu-chol, "Chosŏn sŏngjongdae myŏng ŭi ch'ulbyŏng yoch'ŏng kwa taemyŏng'ŭisik pyŏnhwa,” Han'guksayŏn'gu 169 (June 2015), 105-128.

9 Injo sillok [The Veritable Records of King Injo] (Seoul: Minjokmunhwach'ujinhoe), 34:23a14. Chinese names are romanized in Pinyin while Korean names and terms in Chinese characters are romanized in the McCuneReischauer system. Unless otherwise noted, transliterated terms are Korean. 
out in times of uncertainties as one chief survival strategy.

Under these circumstances, the ruling elites continued to develop NeoConfucianism in a way that rationalized their dominance over Chosŏn and maintained state security. It is Yi Hwang (1501-1571) and Yi I (15361584) that opened up a new horizon of Chosŏn Confucianism by referring to Neo-Confucianism, "that not only philosophically treats coherence and interconnection among cosmos, society, and individuals altogether, but also academically incorporates all Confucian disciplines from metaphysics, to morality, to natural learning, and to state management far beyond the realms of self-cultivation." ${ }^{\text {"10 }}$ Particularly, their theoretical reformulation in terms of Neo-Confucian universalism and practice, reinforced in Cheng-Zhu learning (程朱學), motivated Yi Hwang, Yi I, and their followers to translate timeless order (綱常) into the actual operation of the Confucian term for Universal Pattern (理, $i$ or $r i$ ) in this world encompassing their reality. ${ }^{11}$ To put it another way, it ensured them a constructive form of weltanschauung which validated the Chosŏn establishment and the Ming-centered world system in a more organic manner. ${ }^{12}$

10 Joseph Jeong-il Lee, "Use of Neo-Confucian term for universalism and Practice in Seventeenth-Century Chosŏn Korea", Archiv orientální Vol 84, no.1 (January 2016), 161. In a similar vein, some scholars also illuminate the socio-political meaning of the $i-k i$ debates elaborated by Yi Hwang and Yi I. For instance, refer to Ŏm Yŏnsŏk, “T'oegye ŭi sadanch'ilchŏng kwa kongsa ŭi munje," T'oegyehakpo 115 (June 2004): 45-92; Yi Tuch'an, "Yulgok sugiron ŭi sahoech'ŏlhakchŏk ŭimi," Han'guksasangsahak 24 (June 2005), 313-343. Yi Hwang's followers formed a group called the Southerners 南人 (Namin) while Yi I's followers the Westerners 西人 (Söin). Later, the Westerners were divided into the Old Doctrine 老論 (Noron) and the Young Doctrine 少論 (Soron), the first of which became dominant in central politics from the mid-eighteenth century.

11 Timeless order in Confucianism constitutes the three precepts of human relations; the son must be filial to the father 父爲子綱; officials must be loyal to the king 君 爲臣綱; the wife must be faithful to the husband 夫爲婦綱.

12 Joseph Jeong-il Lee, "Use of Neo-Confucian term for universalism and Practice in Seventeenth-Century Chosŏn Korea," 160. Notwithstanding an ongoing stress on political ideology and pragmatic action, Edward Chung tends to overstate a moral- 
Then, the rise of the Qing was a terribly sensitive matter to the ruling elites because the Qing conquest symbolized disorder running against timeless order. ${ }^{13}$ They had to struggle with the question of where Chosŏn should be placed with the demise of the Ming, the bygone center of Confucian civilization. Critical issues arose regarding how they should come to terms with the "barbarian" rule on mainland China while preserving domestic order under their hegemony in Chosŏn. ${ }^{14}$ For this purpose, these ruling elites paid seminal attention back to the way Yi Hwang and Yi I fathomed the Cheng-Zhu supposition of Universal Pattern and scrutinized how the pattern, never detachable from timeless order, worked in their post-Ming context.

What is more, the Revolt of the Three Feudatories (1673-1681), known also as the Revolt of Wu Sangui in Chosŏn, engendered another layer of uncertainty after the fall of the Ming. During the revolt, the Chosŏn court

ly-oriented and philosophically-driven path of Chosŏn Confucianism and write off the way Yi I reorganized Neo-Confucianism in conjunction with Yi's actual political projects and deeds. Edward Y.J. Chung, The Korean Neo-Confucianism of Yi T'oegye and Yi Yulgok: A Reappraisal of the "Four-Seven Thesis" and Its Practical Implications for Self-Cultivation (New York: State University of New York Press, 1995), 154-161 and 184-185. The metaphysical overrepresentation of Edward Chung decontextualizes, even if unwittingly, Yi's academic engagement in the way essentializing Neo-Confucianism into an invariable, transcendental and ahistorical in particular, standard over all specificities, variabilities, and contingencies.

13 JaHyun Kim Haboush and Marina Deuchler, "Constructing the Center: The Ritual Controversy and the Search for a New Identity in Seventeenth-Century Korea," in Culture and the State in Late Chosŏn Korea, eds. JaHyun Kim Haboush and Martina Deuchler (Cambridge, MA: Harvard University Asian Center, 1999), 46-52.

14 Haboush examines the post-Ming reorganization of Confucian discourse by the ruling elites in late Chosŏn. JaHyun Kim Haboush, "Constructing the Center: The Ritual Controversy and the Search for a New Identity in Seventeenth-Century Korea," 67-72. Please, see also Haboush, "Contesting Chinese Time, Nationalizing Temporal Space: Temporal Inscription in Late Chosŏn Korea" in Time, Temporality, and Imperial Transition: East Asia from Ming to The Qing, ed. Lynn A. Struve (Honolulu, HI: University of Hawaii Press, 2005), 115-141. 
kept collecting information and intelligence regarding the process of the revolt. ${ }^{15}$ The ruling elites brought into relief the competent image of Chosŏn as a politically and culturally self-reliant Confucian state in times of turbulence. To mount an ideological frontline or a stage for Kulturkampf as a counternarrative to Qing dominance proved to be one of the most momentous projects for the elites to settle their highly competitive position in the intellectual community as well as at the political center.

Under these circumstances, the Old Doctrine (老論), or the followers of Yi I, reexamined the relationship between the unity of the Confucian Universal Pattern (理一) and its different manifestation (分殊) with the focus on how to clarify them in human nature. The question of whether human nature is the same or different, as addressed in the previous paragraph, had tremendous implications on what to choose between acceptance and resistance in their response to the Qing-led new order. Noticeable is that through the debate on human nature, the Old Doctrine found themselves split into two diverging camps of Nangnon (洛論) and Horon (湖論) with respect to how to read the new development in which the Qing left behind the turbulent seventeenth century and advanced into High Qing in the early eighteenth century.

The debate within the Old Doctrine, which gave more direct access to central politics, has been explored through the research of Cho Sŏngsan. ${ }^{16}$ Cho examines how the positive attitude of the Nangnon group to the sameness of human nature, predicated on their emphasis on the operation of the Universal Pattern in this world, functioned as a practical route in which to legitimize not only their political creed as regards to factional issues and Qing dominance but also their hegemonic position at the political center. From a macroscopic perspective, Cho suggests the working mechanism of the intellectual community, as well as the Nangnon scholarship, which interweaves the academic refinement with the competence

15 Hyŏnjong kaesusillok [The Revised Veritable Records of King Hyŏnjong] (Seoul: Minjokmunhwach'ujinhoe), 28:12b15-13a4.

16 Cho Sŏngsan, Chosŏnhugi nangnon'gye hakp'ung ŭi hyŏngsŏng kwa chŏn'gae. 
of the political line and the direction of foreign policy.

Still, what is to be more carefully reconsidered is the view of the Nangnon on the sameness of human nature on the grounds that they actually tended to affirm difference in a more subtle yet pragmatist vein with a view to handling the harsh reality of Qing dominance. Any notion of equality or natural rights, as in the case of early modern Europe, was not encouraged by the Nangnon group; instead, the way of thinking about difference, serving as one crucial metaphor for differentiation and division which was socially and politically safeguarded in Chosŏn, was enriched via the language of the differences couched in the Universal Pattern. That is, their flexible attitude towards a constructive relationship with the Qing was profoundly deployed within the framework of containing the difference, open more to a dual structure of self-reliance and coexistence according to change brought by the conquest of the Qing over mainland China, which never belied the inferior status of Chosŏn to the Qing.

Along this line, I will chart in the following how the Nangnon and Horon elites materialized the Confucian vocabularies through the debate on the differences in human nature when the barbarous Qing pushed through its way to the outset of High Qing under the Kangxi Emperor (r. 16611722). More emphasis is put on the way they revitalized the Universal Pattern, or $i$ (理) with the intention of rationalizing the competent seat of Chosŏn under the Qing-led regional order. In so doing, this approach highlights the manner in which the ostensibly conflicting notions of the two groups, formative of scrupulous pertinacity and realistic compromise alike, on difference empowered the Old Doctrine to channel the seemingly abstract concept of human nature into a vital ideological circuit able to revalorize Chosŏn as a land of civilization after the bygone Ming. At this juncture, we will be able to reinterpret the debate on human nature not merely as a scholarly controversy alone but also as a discursive practice during the turbulent epoch of the Ming-Qing transition in East Asia. 


\section{Differences in Kind}

Indisputable and Inherent Differences

One group of the Old Doctrine, called Horon mostly coming from Ch'ungch'ŏng province south of the capital and its environs, expressed their fundamentalist anti-Qing stance. First and foremost, championing timeless order as indispensable to their scholarship, they pursued the spirit of the mid-sixteenth-century reformer movement following Yi I. Specifically, in Yi's stress on the balance between ' $i$ as what penetrates everywhere and therefore unites' (理通, it'ong) and ' $k i$ as what is limited and is therefore limiting (氣, ki)' (kiguk 氣局), they placed high value on the second. ${ }^{17}$ That is to say, they shifted the balance between the Universal Pattern and $k i$ to favor $k i$. What pushed them to this view is Yi's acknowledgment that the Universal Pattern is inevitably confined to the shape of $k i$ (氣質之拘) and associated with the $k i$-driven production of diversity/difference in this world. ${ }^{18}$

Song Siyŏl (宋時烈) (1607-1689), the “architect” of the Horon group, valued the limiting mode of $k i$ which, according to Song, even affected the modus vivendi of the Universal Pattern in this world. For this purpose, Song contrasted the Way (道), inscrutable and unfathomable beyond nomenclature (不可名狀), with this world composed of ki-led forms in vicissitude, and substantiated the variability of $k i$ in this world where nothing

17 Yi I made a balance between it'ong and kiguk in his junction thesis. Joseph Jeongil Lee, "Patterning a Chosǒn-focused Discourse in Yi I's Understanding of $\mathrm{Li}$," 42 43. Apropos the disciplinary continuity from Yi I's $l i-k i$ theory to the debate between the Horon and the Nangnon, see Yi Ch'ŏnsŭng, "Yulgok it'onggiguk kwa horak nonjaeng e kkich'in yŏnghyang," Han'guksasangsahak 25 (December 2005): 39-69.

18 Yi I, Yulgokchŏnsŏ [Collected Writings of Yi I]. Han'guk munjip ch'onggan [The Comprehensive Volumes of Korean Anthologies], 10:15a5-18a4. Unless otherwise stated, personal writings in this article are cited from Han'guk munjip ch'onggan. 
comes before what is variable. ${ }^{19}$ That which is variable, then, turns out to be partial, formable, and value-laden. This orientation helped Song and his Horon group to perceive $k i$ as the primary catalyst which generates the indisputable difference between "the good and the evil" (善惡) and between “the right and the wrong" (是非) in the world. ${ }^{20}$

Moreover, Song agreed with Zhu Xi (朱喜, 1130-1200), whose commentary on Zhou Dunyi's (1017-73) Explanation of the Diagram of Supreme Ultimate (太極圖說) indicated a negative idea on an active operation of the Ultimate (太極), which is the metaphysical source of allpervading and all-inclusive power and the stage before the conductance of the Universal Pattern in this world. ${ }^{21}$ Song re-conceptualized the Ultimate as non-interference (無爲), confined to noumena and detached from the Universal Pattern in phenomena, without doing or moving something in this world. The Ultimate transcends human perception and senses while the Universal Pattern does not precede $k i$ as an all-embracing entity able to perform the Mandate of Heaven (天命).

What is left aside here was the fundamental ground for unity/sameness in an integrative and seamless connection between the Ultimate, as the Universal Pattern defining what is appropriate, and the specific dynamic patterns - $i$ (理) - it generates. The Ultimate is not deemed to be something that is separate from the specific patterns seen in this world. It does not serve as a reference point beyond this world for determining how the

19 Song Siyŏl, Songjadaejŏn [Collected Writings of Song Siyŏl], 131:5b3-6.

20 "What should not be discounted here is that when it came to the human world, differences emanating from $k i$ were always imagined as being open to imperfection, variability, and incompleteness. In a sociopolitical sense, $k i$ might well be thought of as being susceptible to iniquity, corruption, and disorder." Joseph Jeong-il Lee, "Use of Neo-Confucian term for universalism and Practice in Seventeenth-Century Chosŏn Korea," 172.

21 Song Siyŏl, Songjadaejŏn, 131:3b6-4a1. Regarding the importance of this treatise written by Zhou in the formation of the Cheng-Zhu scholarship, see Hoyt C. Tillman, Confucian Discourse and Chu Hsi's Ascendancy (Honolulu, HI: University of Hawaii Press, 1992), 202-211. 
Mandate of Heaven is manifest in this world. Instead, Song saw the Mandate of Heaven as appearing in $k i$, while at the same time he defined $k i$ as that which is in and of itself. ${ }^{22}$ That way Song denied any type of apriority that can handle what is variable in this world and instead stressed the role of $k i$ as a gateway to indisputable and inherent differences.

Han Wŏnjin (韓元震, 1682-1751) delineated Song Siyŏl's theory on the difference. ${ }^{23}$ Following in the footsteps of Song, Han relied on the variability of $k i$ in the junction thesis of Yi I. Han insisted that the Ultimate exists beyond any form in phenomena (太極超形器). ${ }^{24}$ The Ultimate, or the metaphysical source of all-pervading and all-inclusive power and the stage before the conductance of the Universal Pattern in this world, becomes too transcendental to come into this world and meet with the Universal Pattern, a separation of the Ultimate in noumena and the Universal Pattern in phenomena. By so doing, Han not only prevented the Ultimate from intervening in this world as the agency of action, but also disarmed the Universal Pattern of the omnipresent and integrative power over this world.

As a result, the Universal Pattern became impregnated with $k i$-driven form and nomenclature in difference (因氣質而名之) throughout this world. This $k i$-oriented realism gave rise to a compartmentalization of the Universal Pattern without any room for unity/sameness (理絶不同). ${ }^{25}$ The Universal Pattern cannot but undergo an inherent level of difference in itself; even, the Universal Pattern occurs lopsided and unsound in con-

22 Song Siyŏl, Songjadaejŏn, 131:9b5-7; Ibid. at 131:10a1-2.

23 Han Wŏnjin, Namdangjip [Collected Writings of Han Wŏnjin], 28:38b2-5. Han was regarded as the most distinguished Horon scholar after Song Siyŏl. For more information on Han's notion on human nature, refer to Xing Liju and Lin Xi: "Namdang's Theory on the Natures of Humans and Non-Human Living Beings and His Development of Zhu Xi's Theories,"Acta Koreana 9, no.2 (December 2016): 217-234.

24 Han Wŏnjin, Namdangjip, 8:17b8-18a5.

25 Han Wŏnjin, Namdangjip, 7:15b4-5. 
formity with the condition of $k i .^{26}$ When $k i$ is not in action, still, the difference is inscribed a priori. The difference exists in itself.

This differentiation also allowed Han to eliminate differences between one human being and another in the state before the Patterns that direct behavior has begun to do so (未發). ${ }^{27}$ The dynamic Patterns do not produce differentiation by themselves. The original nature of the universally dynamic Pattern (本然之性) is implied in and of itself. It is the human mind-and-heart that creates difference. This led Han to highlight differences according to a dichotomy that distinguishes the good and the right from the evil and the wrong. Some people are born good but some are not. Along this line, Han employed a definite nomenclature (定名) and an essentialized substance (定體), both of which determined all kinds of differences in themselves.

Likewise, the emphasis of Song Siyŏl and Han Wŏnjin on the variability of $k i$ revitalized a competitive form of $k i$. Song and Han counted out the transcendence of the Ultimate and the providence of the Universal Pattern, thereby making the Ultimate and the Universal Pattern invisible in this world. What was deterred is any interpretation that valorizes an actual force of the Ultimate and a transformative interposition of the Universal Pattern, available for unity and integration, in phenomena. Their $k i$ oriented theory disavowed an active presence of the Universal Pattern in this world and withheld a constructive and affirmative engagement with various issues caused by difference. In so doing, Song and Han fully authorized $k i$ as the sole agency that propels the operation of this world in difference.

\section{Han Wŏnjin, Namdangjip, 8:15b8-16a4.}

27 Han Wŏnjin, Namdangjip, 11:45b6-9. In regards to Han's exposition on the state of non-manifestation of Universal Principle (理), see Hong Chŏng'gŭn, "Namdang Han Wŏnjin ŭi mibalsim samch'ŭnggujo koch'al," Han'guksasangsahak 21 (December 2003): 417-445. 
The Difference in a Fundamentalist Turn

Who, then, would be eligible to administer a proper action of $k i$, more specifically the operation of difference, in seventeenth-century Chosŏn? Song Siyŏl warned against any regal absolutism in attempts to manage the details of state affairs personally (自親細務). ${ }^{28}$ In lieu of a strong monarchy, Song brought up public opinion (公論) or public righteousness (公 義) suitable for a government led by righteous and qualified ruling elites-the Old Doctrine. ${ }^{29}$ Alongside this, Song promoted the role of the prime minister in marshaling these elites, taking the helm of the administration, and carrying out policies. The emphasis on the government under the control of the prime minister apprises us of how Song would represent the Old Doctrine as the most legitimate player able to manage the differences in Chosŏn and beyond. ${ }^{30}$

Song disagreed with King Hyojong (孝宗, r. 1649-1659) regarding the impartial policy (蕩平) in which kings take the lead in central politics and appoint able people to the court irrespective of their political creed. ${ }^{31}$ What was to be taken into consideration, Song highlighted, is the political reality where an invariable difference was entrenched among political groups and a conversion or agreement is impossible. For instance, baneful herbs cannot be planted along with aromatic herbs; ice and charcoal cannot be contained in a bowl together, either. Thus, Song argues that a king needs to discriminate the sagacious and the unwise and reach the goal of

28 Song Siyŏl, Songjataejŏn, 5:18b4-19a2.

29 Kim Chunsŏk, Chosŏnhugi chŏngch'isasangsa yŏn'gu. Seoul: Chisiksanŏpsa, 2003, 246-266.

30 Chŏng Chaehun talks about how Zhu Xi's political theory had bearing on the argument of Song Siyŏl for political participation in central politics by elucidating the development of Zhu's discourse on a tight partnership between ruler and minister into the Song's stress on the Old Doctrine-led public politics. See Chŏng Chaehun, "Uam Song Siyŏl ŭi chŏngch'isasang-Chuhi wa ŭi pigyo rŭl chungsim ŭro," Han'guksasangkwamunhwa 23 (2004): 63-90.

31 Song Siyŏl, Songjataejŏn, 6:22a4-7. 
being without prejudice.

The explicit claim for the leadership of the ruling elites over the king, proposed by Song and his Horon group, would go against the crown and power elites at court. The conversation between King Yŏngjo (英祖, r. 1724-1776) and a secret censor Yi Ch’ŏlbo (李喆輔, 1691-1775) exudes the attitude of the central government regarding the Ch'ungch'ŏng area-the base of Song and his Horon adherents. ${ }^{32}$ Yi reported how the local leaders in that region insulted the authority of the secret censor, directly dispatched from the court, and tried to arbitrarily control their local community. Actually, a good part of the governmental policies apropos land property, military, welfare, taxation, and the like would conflict with the exclusive privileges and rights of the local elites including the Horon group in Ch'ungch'ŏng province.

Han Wŏnjin carried on the political discourse of Song Siyŏl to attack anti-Song groups even including some of the same Old Doctrine. Han's formation of a confrontation structure between the good and the evil and between the right and the wrong did form an intense rivalry at the political center. Arguments deviating from the Horon's view were stigmatized as an unbearable error of 'making humanity and bestiality undifferentiated' (人獸無別, insumubyŏl). ${ }^{33}$ Han discredited such prominent elites from the Young Doctrine as Pak Sech'ae (朴世采, 1631-1695) and O Toil (吳道一, 1645-1703). Even, without hesitation Han struck those who belonged to the same Old Doctrine, including Cho Sŏnggi (趙聖期, 16381689), Kim Ch'anghyŏp (金昌協, 1651-1708) and Kim Ch'anghŭp (金昌 翕, 1653-1722) from the Nangnon. ${ }^{34}$ Han's exclusivist attitude towards other political or intellectual groups, concurrent with his belief in the Horon as the single partner of the king at court, collided with the impartiality policy. In fact, distrust between Yŏngjo and Han was reflected in the king's response to one of Han's memorials against the policy. In a memo-

32 Yŏngjo Sillok [The Veritable Records of King Yŏngjo], 42:27b11-28a8.

33 Han Wŏnjin, Namdangjip, 8:16b8-17a4.

34 Han Wŏnjin, Namdangjip, 29:1a1-6b4; 29:20b3-21a6; 29:21a8-25b4. 
rial to King Yŏngjo in 1731, Han expressed his disagreement on the impartiality policy. ${ }^{35}$ The king directly expressed his displeasure towards Han's offensive memorial by rebutting Han's faction-centered posture as an impertinent and self-obsessed political line void of respect for the court. $^{36}$

Most of all, Song and Han applied the motto of "making humanity and bestiality differentiated" to the relationship with the Qing. To be precise, an unyielding stance for Ming loyalism in the post-Ming period was the keyword of their anti-Qing movement. Acknowledging the inevitable situation under Qing dominance, however, Song criticized in a lengthy memorial to King Hyojong pragmatist and pacificatory opinions for a constructive Chosŏn-Qing relationship. ${ }^{37}$ Those who ascertain the necessity of this approach, according to Song, are to be categorized as false prophets not only goading people to the ilk of birds and beast (禽獸之類), ignorant entirely of what it means to be a son and what it means to be a father, but also rejecting the teaching of Confucius.

Han inherited Song's dichotomy between humanity and bestiality against the Qing. In a royal lecture before King Yŏngjo in 1726 Han stated that the name of the Mongolian empire before the reign of Quibilai (r. 1260-1294) should be recorded as Mongol (蒙古) not Yuan (元). ${ }^{38}$ If Yuan stands out from the very outset of the Mongolian conquest, this retrospective naming gives it the prominence that it does not deserve. Historically speaking, the pre-Quibilaian Mongols did compete with the Jurchen Jin and the Han-Chinese Song, both of whom represented themselves as the legitimate rulers for mainland China during the period. Han would not accord any respect to the Mongolian empire but reinforced his deep reservation about Mongolian legitimacy by referring to his teacher Song Siyŏl's denial of the Yuan as the legitimate successor (正統, chŏngt'ong).

35 Han Wŏnjin, Namdangjip, 29:44a9-b8.

36 Yŏngjosillok 29: 45a9-12; Han Wŏnjin, Namdangjip, 30:4b12-5a2.

37 Song Siyŏl, Songjataejŏn, 5:28b10-29a5.

38 Han Wŏnjin, Namdangjip, 6:18b5-9a1. 
Han even predicted a breakdown of the Qing on the grounds that the Qing conquest was merely an act of fishing in troubled waters, gained amid the rebellion of Li Zhicheng (1606-1645) and the betrayal of $\mathrm{Wu}$ Sangui, without any profound grand design. ${ }^{39}$ In addition, their rule ran for a century while the grave power struggle under the Yongzheng Emperor (r. 1722-1735) took place. What Han found out from historical research is that a successor to a predecessor with a long reign would face numerous troubles. The Youngzheng court after the long sixty-year reign of the Kangxi Emperor (r. 1661-1722) met that condition past the century-long dominance over mainland China. A Qing collapse, Han surmised, would occur in accord with the demise of the Yongzheng Emperor.

What is more, Han also explained to King Yŏngjo a post-Qing scenario where a retreating Qing might move to the eastern area of the Liao River and keep plundering the borderland of Chosǒn. ${ }^{40}$ The reason, Han pointed out, is that a new (Han-Chinese) dynasty could not immediately reach the Liaodong Peninsula in chase of a faltering Qing, which then would utilize two advance bases of Liaoyang (遼陽) and Shenyang (潘陽) behind which the last stronghold Ningguta (寧古塔, the current Ning'an (寧 安)) lurked. Since the beginning of their conquest, the Qing court had militarized the three cities with provisions, sufficient to distress the border security of Chosŏn after their withdrawal from Peking and to continue their influence on Chosŏn. He warned that the court should prepare for an anti-Qing campaign even after the fall of the Qing in the future.

Ultimately, with a definite exclusion of the Qing from the domain of legitimacy, Han confessed his allegiance to the civilization of Chosǒn. ${ }^{41}$ Han reminded King Yŏngjo of the role of the Horon in the grand project in which their two masters, Yi I of the sixteenth century and Song Siyŏl of the seventeenth century, should be elevated as the successors to Confucius and Zhu Xi. What made Han draw such an audacious conclusion?

39 Han Wŏnjin, Namdangjip, 6:4a8-b5.

40 Han Wŏnjin, Namdangjip, 6:4b5-5a2 and 6:30b9-31a7.

41 Han Wŏnjin, Namdangjip, 6:37a8-38a2. 
Mainland China, he diagnosed, had gone effete and decadent due to a series of barbarian conquests. Zhu Xi revitalized the teaching of Confucius but no one kept their teaching alive after the Southern Song. On the contrary, Chosŏn had been significantly achieving cultural government (大興文明之治) and generating true scholarship in Confucian teaching (眞 儒). That is how Chosŏn came to remain as the only place of Confucian civilization after the fall of the Ming and amidst the dominance of the Qing. We can chart here how the Horon's self-confidence, constructed theoretically upon their emphasis on the agency of $k i$ and their interpretation on difference, cast light on a culturally competent Confucian state of Chosŏn.

Song and Han tried to prove that the differences emerge as what universally constitutes this world. In this process, differences were explained through a normative designation of human nature in which "ontological" differences, or differences in kind, were emphasized. Their attention to the role of $k i$ in begetting indisputable and inherent differences in this world, including a difference between Chosŏn and the Qing as well as a difference between humanity and barbarity, attracted a considerable number of the Old Doctrine, who took an intransigent posture against the Qing. As ever, they remembered the Qing as barbarians for centuries just before the first half of the seventeenth century while pursuing revenge, if mentally and psychologically, against the Qing for the humiliating defeat in 1637. Therefore, the stress of Song and Han on the dynamics of $k i$ in a dichotomist manner helped reset the Old Doctrine's posture in a fundamentalist, exclusive and uncompromising tone against the Qing, professed the cultural pride of Chosŏn on the move, and created a specific space unavailable for any Qing intervention, which meant an ideological frontline beneath the geopolitical reality of Qing hegemony. ${ }^{42}$

42 The conservative stance of Song and Han vividly passed down to the next generations of the Horon scholarship and gave a foothold in the "Protect the Orthodox, Repel the Heterodox (Wijŏngch'ǒksa, 衛正斥邪) movement during the nineteenth century. Kim Ch’angsu: “19segi huban, chibang chisigin ŭi taewaeinsik chihyŏng 


\section{Differences in Degree}

The Difference in Balance

With “the omnipresent workability of the Universal Pattern" (理通, it'ong) in Yi I's thesis, some scholars of the Old Doctrine or Nangnon explored the difference in a comprehensive way. Cho Sŏnggi, the forerunner of the Nangnon group, made much of the all-pervasive character of the Universal Pattern piercing through humankind and nature altogether (一以貫之). ${ }^{43}$ Cho exploited both transcendence and immanence of the Universal Pattern in such a way that the Universal Pattern prevails over the existence of things (未有物而已有所以爲是物之理, transcendence) while making no separation from things (未嘗懸空獨立, immanence). ${ }^{44}$ The binary movement of transcendence and immanence under the omnipresence of the Universal Pattern confirmed the inseparable relationship between the Universal Pattern and $k i$ (理無無氣之理氣無無理之氣). ${ }^{45}$

As the animateur in a position to materialize all things in form (所能形是 物者), according to Cho, ki does afford original and massive components to all things in this world. The basic pattern of what the things are meant to be as they are (所以爲是物者), however, consists in the Universal Pattern; $k i$ plays a role as an implementer of the Universal Pattern (爲理所命). The power source for action is grounded upon the inherent property of the Universal Pattern (理之本然) behind and beyond ki. So, Cho reformulated the balance between the Universal Pattern and ki to the advantage of the first.

Kim Ch'anghyŏp, the other towering master of the Nangnon, also admitted the inseparability of the Universal Pattern and $k i$ in balance. ${ }^{46}$ Kim

-Hwasŏhakp'a ŭi hwaigwan kwa ch' ŏng insik ŭl chungsim ŭro-," Han'guksahakpo 72 (August 2018): 86-100.

43 Cho Sŏnggi, Cholsujaejip [Collected Writings of Cho Sŏnggi], 10:31a4-7.

44 Cho Sŏnggi, Cholsujaejip, 11:9b10-10a9.

45 Cho Sŏnggi, Cholsujaejip, 11:11a5-b5.

46 Kim Ch'anghyŏp, Nong'amjip [Collected Writings of Kim Ch'anghyŏp], 32:15a10-b6. 
pointed out that fixation on how to identify the Universal Pattern with a specific type of existence would be the fundamental error. The conceptualization of the Universal Pattern as a nonmaterial existence results not only in a dissociation of the Universal Pattern from $k i$, but also a devaluation of the Universal Pattern as a self-motion outsider in a certain remote place (懸空自運). The segmentation mischaracterizes, as the Horon did, the Universal Pattern as a hypothetical and torpid type of existence.

Kim also revitalized the Universal Pattern (無形有爲) as the unsurpassable agency that occasions both being (自然, sein or what-is-so) and norm (當然, sollen or what-should-be-so). ${ }^{47}$ Undoubtedly, the Universal Pattern is identified as the sublime actor of causation whereas $k i$ was employed as an implement ordered by the Universal Pattern (命乎理). Kim rebutted the role of $k i$ as a substitute for the Universal Pattern in this world and counteracted any $k i$-tilted position. The transcendental idealism as shown above makes the Universal Pattern stand in a position to mediate all visible and invisible entities and to contain noumena and phenomena, together.

By creating a point of consolidation with the Ultimate, Kim Ch'anghŭp, another leader of the Nangnon, also expounded the omnipotence of the Universal Pattern with an emphasis on its causative agency. ${ }^{48}$ Kim started with the connection between the Ultimate and the Universal Pattern to authorize the latter to wield a cosmic and transcendental source of power

47 Kim Ch'anghyŏp, Nong'amjip, 32:16a1-7.

48 Kim Ch'anghŭp and Kim Ch'anghyŏp came from the Andong Kim clan, one of the core members of the Nangnon within the Old Doctrine. The Kims' father, Kim Suhang (1629-1689), was executed at the second turnover under the Southerners' cabinet at court while their older brother Kim Ch'angiip (1648-1722) was executed during the political debacle of Kyŏngjong's period (r. 1720-4) in confrontation with the Young Doctrine. The Kim brothers played a crucial role in Nangnon scholarship in such fields as political theory, statecraft, arts, literary criticism, aesthetics, philosophy, and classicism. Regarding the Kims' contribution to the academic attributes of the Nangnon, see Yi Ch'ŏnsŭng, "Nong'am Kim Ch'anghyŏp ŭi sasang kwa nakhak ŭro ŭi yŏnghyang,” Chosŏnsidaesahakpo 29 (June 2004):137-160. 
descending upon all things, including human beings, of this world. What is possible from this uninterrupted oneness is an ontic presence of the Ultimate (太極之眞象) in justifying the operation of the Universal Pattern in this world. ${ }^{49}$ The ubiquitous yet substantive movement of the Ultimate, then, takes a freer step for an expansion of its working heft, both inseparable from the Universal Pattern and embedded in $k i$, into this world. ${ }^{50}$ It means that every process of energization and materialization in the movement of $k i$ involves, to say nothing of the Universal Pattern, the U1timate. This deliberation buttresses the actual power of the Universal Pattern across the natural realm and the social realm alike and reconfirms the Universal Pattern as the essence (本體) and totality (統體) of $k i{ }^{51}$ At this juncture, $k i$ is subordinated both to the Ultimate and the Universal Pattern, a counterpoise to Han Wŏnjin's disjuncture between the Ultimate in noumena and $k i$ in phenomena (太極超形氣) as well as Song Siyŏl's $k i$ centered interpretation of the Ultimate as absent-cause segregated totally from this world.

What is more, Kim underscored an originally pure, transparent, and benevolent basis of human mind-and-heart as the instantiated substance of the Universal Pattern. ${ }^{52}$ Being the container of the Universal Pattern, saturated already with the Ultimate, human mind-and-heart is to embody the substance of the Universal Pattern in a state of being good and perfect. In other words, the universally innate goodness, purity, transparency, and perfection of human mind-and-heart are programmed within human nature. So, a proper reception and manifestation of the Universal Pattern is set as the barometer for the boundary between goodness and iniquity. That is why occasional incompletion, impediment, and impairment are not so much immovable or fixed as prone to change or improvement.

All in all, Cho Sŏnggi, Kim Ch'anghyŏp, and Kim Ch'anghŭp from the

49 Kim Ch'anghŭp, Samyŏnjip [Collected Writings of Kim Ch'aghŭp], 18:3a8-b3.

50 Kim Ch'anghŭp, Samyŏnjip, 33:3b4-9.

51 Kim Ch'anghŭp, Samyŏnjip, 18:2a2-6.

52 Kim Ch'anghŭp, Samyŏnjip, 33:32b6-33a7. 
Nangnon withstood any predestinated and dichotomist elements in human nature, to the point of relaxing the dichotomy between the sages (聖人) and ordinary people (凡人). ${ }^{53}$ Differences exists in degree rather than in kind. This rearrangement of differences in tune with change, improvement and balance delegitimized Song and Han's determinist interpretation on indisputable and inherent differences of human nature. Besides, their adherence to the original goodness of human nature encouraged the Old Doctrine to take an integrative and adaptive policy line, including a constructive relationship with the Qing. In the next, we will see how the accommodative approach of Cho and the Kim brothers laid the foundation for the other response of the Old Doctrine to the undiminished Qing.

The Difference in an Adjustable Orientation

The appreciation of Cho Sŏnggi, Kim Ch'anghyŏp, and Kim Ch'anghŭp for public space and balance heightened the role of the Nangnon as a competitive mediator capable of re-stabilizing society under the control of the political center and rephrasing the vital progress of the barbarian Qing regime from their vantage point. Cho Sŏnggi criticized the all-out yet fruitless strife between the leader of the Horon group, Song Siyŏl within the same Old Doctrine and the key figure of the Young Doctrine Yun Chŭng (1629-1714). With a strong commitment to state affairs as the priority, Cho made it clear that both sides entirely left out state affairs for the sake of their own factional agenda. ${ }^{54}$

Kim Ch'anghyŏp carefully evaluated the merits and demerits of the commandery-district kunhyŏn (Ch. junxian) system (郡縣制) and the feudal ponggŏn (Ch. fengjian) system (封建制), and sided with the kunhyŏn system. ${ }^{55}$ The kunhyŏn system was initially designed by the ambitious

53 Cho Sŏngsan, Chosŏnhugi nangnon'gye hakp'ung üi hyŏngsŏng kwa chŏn'gae, 121-202.

54 Cho Sŏnggi, Cholsujaejip, 6:15a6-10.

55 Kim Ch'anghyŏp, Nong'amjip, 32:20b6-22b6. For more reference to this matter, 
Qin (秦) unifier to integrate China into his own hands (欲以天下秦一人). But, it also brought out an unexpected breakthrough for a fair and open recruitment of the virtuous, competent, and talented for statecraft.

Along this line, in a memorial to King Sukchong (r. 1675-1724) Kim illuminated the significance of historical study for royal discernment and judgment. ${ }^{56}$ Rulers should increase their knowledge of history in order to illuminate the undivided full picture (統體), including a lifespan of a polity in its entirety as well its mores and vicissitude, for the affairs of their state. A holistic viewpoint, Kim contended, would provide the rulers with a balanced perspective to rectify their own biases and to attain impartial rightness (中正). In addition to this compendious point of view, what was to be achieved for a kingly rule was to get to the crux of problems at hand (機括) and to treat a task carefully with a full and detailed comprehension of the consequences. Needless to say, Kim's two-tiered method of illuminating the entire undivided picture-the whole - and getting to the crux of problems at hand-the part- in balance was devised for an unprejudiced completion of state matters under regal leadership.

In a similar vein, Kim Ch'anghŭp carefully readdresses the retrospect and prospect of the ponggón systems. ${ }^{57}$ In China, the system, originating from the Zhou (1046-256 BC), continued into the Five Dynasties (907960). As late as the Former Han (202 BC-9 AD), the traditional manner of enfeoffment drove feudal lords in endeavors to confront the central polity, stand for themselves, and compete against one another for hegemony. After the dispatch of the Inspector (刺史) to localities in Latter Han, puissant ministers at the court (權臣) vigilant for displaying their political prowess, emerged as new competitors in the power game. The fanzhen (藩鎭) system of the Tang (618-907), implemented against the rampancy of decentralizing elements, wound up again in a type of decentralization.

see Cho Sŏngsan: "18 19segi chosŏn ponggŏn-kunhyŏnje nonŭi ŭi yŏksajŏk chŏn'gae, Yǒksahakppo 236 (December 2017): 266-270.

56 Kim Ch'anghyŏp, Nong'amjip, 10:a4-b8.

57 Kim Ch'anghŭp, Samyŏnjip, 36:11a1-11b2. 
The Song (960-1279) kept a tight rein on the military personnel in localities, especially the border areas, but as a result received numerous invasions from the barbarians due to the weaker security situation.

Kim made two points for a better measure of the ponggŏn system. ${ }^{58}$ The root of these repetitive problems lied in either excessive expansion or reduction. This disproportionate treatment had produced an adverse reaction against the political center and fell into political disintegration, culminating in the level of "weak rulers and strong ministers" (君弱臣强, kunyak sin'gang). Kim considered the severe undermining of sovereign power to be the cardinal challenge to how to reform the system. Seeing through the drawbacks of the dysfunction of the ponggon system, the Song rulers overly stripped of operational authority in local districts targeted mostly frontier military bases and reorganized these administrative units under the kunhyŏn system, leaving the front lines bereft of armaments and provisions. That is, Song rulers did not pay much attention to how to adjust and coordinate local bureaus in communication with the political center, but preoccupied themselves with how to debilitate the local organizations deployed in defense of the border areas. Here, Kim affirmed that the lesson from the Song was a competent leadership able to maneuver the adroitness of 'evening out the shortage of work force/work resource and regulating things fittingly according to situations' (全欠勘酌).

At the same time, the common ground of Kim Ch'anghyŏp and Kim Ch'anghŭp for overall balance, judicious objectivity, and all-embracing perspective were markedly instrumental in their flexible interpretation of the presence of the Qing. As for the Chosŏn court and ruling elites, (re-) establishing the dynastic legitimacy of imperial China was not only an ethical question but also an ideological lynchpin in which to decide which states were the guides of the Confucian civilization and which the models were for Chosŏn. In particular, given that mainland China was being unified under the Qing, the above issue was directly associated with how to address the authority of the Qing.

58 Kim Ch’anghŭp, Samyŏnjip, 36:11b4-12a1. 
Staying away from the popular opinion which prioritized the Han Chinese states in the legitimate line over the non-Han Chinese, or barbarous states, Kim Ch'anghŭp construed the meaning of (正, chŏng) as that which is evenhandedly placed in the middle less than that which is upright in counter to be malevolent. ${ }^{59}$ More noticeably, Kim opposed the prevailing notion attaching, without doubt, to barbarity the negative side of human nature such as iniquity and perniciousness. ${ }^{60} \mathrm{Kim}$ 's value-free track against a blind overgeneralization of non-Han Chinese states as illegitimate paved the way for an exhaustive standard into which the barbarian, the Han-Chinese, the good, the iniquitous, the righteous, and the wrong are dissolved altogether. It can be said that the ethnic dichotomy of barbarism and civilization in juxtaposition to the non-Han Chinese and the Han Chinese respectively, intertwined with the value system, desists. The qualification for legitimacy, Kim declared, only rests upon whether mainland China is unified and its surrounding areas are pacified. This interpretation is a clear contrast to the value-oriented exposition of the Horon, as previously explained, on the Qing reunification merely as a disqualified occupation of mainland China.

The diachronic, objective, and flexible reading of legitimacy by Kim Ch'anghŭp passed on to Pak P'ilchu (1680-1748). Pak's attitude on the legitimacy question drew on the vital movement of the Universal Pattern, theorized profoundly by his Nangnon predecessor Cho Sŏnggi, Kim Ch'anghyŏp and Kim Ch'anghŭp, in this world. Specifically, how to understand the interactive operation of the Universal Pattern in a set of integration and disintegration (天下之理分而合合而離) in this world is pivotal to Pak's understanding of the dynastic rise and fall. ${ }^{61}$

With this metaphysical theme in mind, Pak P'ilchu mentioned the coexistence or succession between the barbarian states and the Han-Chinese

59 Kim Ch'anghŭp, Samyŏnjip, 36:12b5-7.

60 Cho Sŏngsan, Chosŏnhugi nangnon'gye hakp'ung ŭi hyŏngsŏng kwa chŏn'gae, 186-187.

61 Pak P'ilchu, Yŏhojip [Collected Writings of Pak P'ilchu], 32:17b7-18a1. 
states and underscored the rules of the Yuan, the Ming, and the Qing as a marker for their status of a unified empire regardless of their ethnic origin. ${ }^{62}$ In the process, Pak accepted, if implicitly, the authority of the Qing, which was sailing for High Qing, by way of replacing legitimacy with longevity. He even predicted that a reunification of a Han-Chinese state in place of the Qing might be a touch mission and instead of one new state a type of Southern-Northern Courts (南北朝) could emerge. ${ }^{63}$ This view is at odds with Han Wonjin's forecast about the fall of the Qing in the near future especially after the demise of the Yongzheng Emperor.

Furthermore, Pak reevaluated the invincible power of the Jin-the Jurchen predecessors to the Qing-, rising from the northern frontier of mainland China, able to subjugate the Song and stretch almost to the level of total unification (一統無異). ${ }^{64}$ The reposition of the Jin in the genealogy of imperial China exemplified Pak's gentle yet courageous approach to the legitimacy of the later barbarian states, or the Yuan and the Qing. In so doing, it seems, he rendered the cycle of hegemonic conflict between Han Chinese and non-Han Chinese states as a fait accompli to endorse the recognition of the Qing legitimacy as the status quo.

This realist stance was amply reflected in his conviction for the abiding significance of Peking. ${ }^{65}$ The Ming, according to Pak, moved out of necessity its capital from Nanjing to Peking with the intention of controlling the barbarian forces in the north; in the course, it was severely defeated by them due to its geographic proximity to their borderlands. But at its zenith, Ming dominance proved to be an archetypal rule over the northern forces. Therefore, Pak conjectured, whoever becomes the new unifier after the Qing is likely to settle its capital at Peking. A Han Chinese polity needed to emulate the governing measure of the Ming against the northern barbarians. In the case of a non-Han polity, Peking would not be dis-

62 Pak P'ilchu, Yǒhojip, 32:17b10-18a1.

63 Pak P'ilchu, Yŏhojip, 32:18a1-2.

64 Pak P'ilchu, Yǒhojip, 32:18b1-7.

65 Pak P’ilchu, Yǒhojip, 32:19a1-5. 
tant from its homeland. We can learn here how Pak's flexible standpoint on the barbarian states in the legitimate lineage of imperial China could be conducive to a future-oriented macro-strategy vis-à-vis changes in imperial China as well as a recognition of Qing hegemony per se.

Nonetheless, the positive approach of Kim Ch'anghyŏp, Kim Ch'anghŭp and Pak P'ilchu to Qing authority was far from a sycophant mode of toadyism. But, it functioned as a flexible form of relativism, inspired theoretically by the ubiquitous and active operation of the Universal Pattern in this world, in posing Chosŏn, the Qing, and a Han-Chinese polity altogether at a collinear level. By this logic, Chosŏn could be equitably treated with the Qing and the Han Chinese polity. It is this reciprocal thought that enabled Hwang Kwŏng'wŏn (1709-1787), a core member of the later Nangnon after Kim Ch'anghyŏp, to distinguish proprieties and decorum (禮義)—civilization in general一utterly from ethnic and geographical elements. ${ }^{66}$ That is why Hwang petitioned for convertibility in which the transformation of a barbarian entity, when equipped with proprieties and decorum, into a center of civilization is made possible. In this vein, Kim Ch'anghyŏp, Hwang's senior, singled out the post-Ming preservation of civilization in Chosŏn and proclaimed, in a strikingly similar way to Han Wŏnjin from the Horon, Chosŏn as "Another Center of Civilization" (小中華, Sojunghwa) outside of mainland China. ${ }^{67}$

To put it briefly, Cho Sŏnggi, Kim Ch'anghyŏp, and Kim Ch'anghŭp from the Nangnon tried to prove that difference/diversity works in the operation of the Universal Pattern. In that process, human nature, whose difference-difference in degree, can be regulated and changeable in balance. This notion inspired them to break down the dichotomy between humanity and barbarity, chart a possibility of transformation from the barbarous to the civilized, and reevaluate the stature of non-Han Chinese states in imperial China. Their emphasis on the earthly and actual power

66 Hwang Kyŏng'wŏn, Kanghanjip [Collected Writings of Hwang Kyŏng'wŏn], 5:39b2-5.

67 Kim Ch'anghyŏp, Nong'amjip, 22:22b2-6. 
of the Universal Pattern in a comprehensive mode offered a space of engagement to the Old Doctrine who strategized for a flexible, objectivist, and accommodative stance to the Qing.

\section{Concluding Remarks}

Since their devastating defeats to the Qing in 1627 and 1637 and the fall of the Ming in 1644, the Chosŏn court and the ruling elites had been struggling with the question of how to justify the new regional order under Qing dominance. To be certain, the military imbalance did not keep them from dichotomizing civilization and barbarity and mobilizing the ideological and culturalist strategies in the face of the invincible Qing. Throughout the debate in the late seventeenth and early eighteenth centuries, as demonstrated in this article, the Old Doctrine maximized Confucian terminologies, centering on the Universal Pattern, to their bifurcating understanding of difference-difference in kind by the Horon and difference in degree by the Nangnon-and enlivened a Janus-faced response to the powerful Qing in terms of self-reliance and collaboration. In other words, Confucian universality was employed as an ideological metalanguage capable of fashioning difference in another hegemonic tone, concurrent with Qing dominance, and alternating pro-Qing and anti-Qing lines without mislaying their capacity for engagement in the changing world of East Asia. What makes these findings substantial? On the one hand, we can locate an intense dialogue between Confucianism and power relations, where Chosŏn stood firm, if internally, in counter to Qing dominance. On the other hand, the interpretive contrast between the Horon and the Nangnon catalyzed a flexible mode of treating differences, sufficient to brandish both compromising and uncompromising gestures in relation to the Qing, i.e., a division of labor which reasserted the leadership of the Old Doctrine in the anti-Qing discourse. These two aspects will inspire us to revisit how the Chosŏn elites, including the Old Doctrine, redesigned Confucianism on their terms under the Qing-led regional 
order and revalorize Chosŏn as a self-sustaining realm of civilization.

\section{References}

Primary Sources:

1. Hyŏjong sillok [The Veritable Records of King Hyŏjong]

2. Hyŏnjong kawsu sillok [The Revised Veritable Records of King Hyŏnjong]

3. Injo sillok [The Veritable Records of King Injo]

4. Yŏngjo sillok [The Veritable Records of King Yŏngjo]

6. Cho Sŏnggi. Cholsujaejip [Collected Writings of Cho Sŏnggi]. In Han'guk munjip ch'onggan [The Comprehensive Volumes of Korean Anthologies], vol. 147. Seoul: Han'guk kojŏn pŏnyŏgwŏn, 1995.

8. Han Wŏnjin. Namdangjip [Collected Writings of Han Wŏnjin]. In Han'guk munjip ch'onggan [The Comprehensive Volumes of Korean Anthologies], vols. 201-202. Seoul: Han'guk kojŏn pŏnyŏgwŏn, 1998.

9. Hwang Kwŏng’wŏn. Kanghanjip [Collected Writings of Hwang Kwŏngwŏn]. In Han'guk munjip ch'onggan [The Comprehensive Volumes of Korean Anthologies], vols. 224-225. Seoul: Han'guk kojŏn pŏnyŏgwŏn, 1999.

10. Kim Ch'anghyŏp. Nong'amjip [Collected Writings of Kim Ch'anghyŏp]. In Han'guk munjip ch'onggan [The Comprehensive Volumes of Korean Anthologies], vols. 161-162. Seoul: Han'guk kojŏn pŏnyŏgwŏn, 1996.

11.

. Nong'amjip sokchip kwŏn ha [Additional Writing of Kim Ch'anghyŏp II]. In Han'guk munjip ch'onggan [The Comprehensive Volumes of Korean Anthologies], vol. 162. Seoul: Han'guk kojŏn pŏnyŏgwŏn, 1996.

12. Kim Ch'anghŭp. Samyŏnjip [Collected Writings of Kim Ch'aghŭp]. In Han'guk munjip ch'onggan [The Comprehensive Volumes of Ko- 
rean Anthologies], vols. 165-167. Seoul: Han'guk kojŏn pŏnyŏgwŏn, 1996.

13. Pak P'ilchu. Yǒhojip [Collected Writings of Pak P'ilchu]. In Han'guk munjip ch'onggan [The Comprehensive Volumes of Korean Anthologies], vols. 196-197. Seoul: Han'guk kojŏn pŏnyŏgwŏn, 1997.

14. Song Siyŏl, Songjadaejŏn [Collected Writings of Song Siyŏl]. In Han'guk munjip ch'onggan [The Comprehensive Volumes of Korean Anthologies], vols. 112-120. Seoul: Han'guk kojŏn pŏnyŏgwŏn, 1993.

15. Yi I, Yulgokchŏnsŏ [Collected Writings of Yi I]. In Han'guk munjip ch'onggan [The Comprehensive Volumes of Korean Anthologies], vols. 44-45. Seoul: Han'guk kojŏn pŏnyŏgwŏn, 1988.

Secondary Sources:

16. Braudel, Fernand. On History, translated by Sarah Matthews. Chicago: The University of Chicago Press, 1980.

17. Chi Tuhwan. Chosŏnsidae sasangsa ŭi chae chomyŏng. [Rethinking History of Thought in Chosŏn] Seoul: Yŏksamunhwa, 1998.

18. Cho Sŏngsan. Chosŏnhugi nangnon'gye hakp'ung ŭi hyŏngsŏng kwa chŏn'gae. [The Formation of the Nak School in the Late Choson Dynasty: Its Academic Tradition and Statecraft Thought] Seoul: Chisiksanŏpsa, 2007.

19. . "Yŏn'am gŭrŭp ŭi ijŏk nonŭi wa ch'unch'u." [Perspectives on the Barbarian: The Yornam Group's Discourse and Ch'unqiu's Views] Han'guksayŏn'gu 172 (December 2016): 223-263.

20. __ . "Hong Taeyong ŭi igisimsŏngnon kwa chiyŏkch'unch'u nonŭi." [Chuqiu (spring and autumn annals) Outside China and its Philosophical Basis Presented by Hong Dae-yong] Yǒksa wa Tanmon 78 (September 2016): 145-198.

21. ___ " “ $18 \sim 19$ segi chosŏn ponggŏn kyunhyŏnje nonŭi ŭi yŏksajŏk chŏn'gae.” [The Historical Development of the Fengjian (封建, feudal system) vs. Junxian (郡縣, rational bureaucracy) Debate of the Eight- 
eenth and Nineteenth Century Chosŏn Intellectuals Community] Yŏksahakppo 236 (December 2017): 253-301.

22. Chŏng Chaehun. "Uam Song Siyŏl ŭi chŏngch'isasang - Chuhi wa ŭi pigyo rŭl chungsim ŭro." [Studies on the Political Ideologies of Song, Si-yeol-compared with Chu His] Han'guksasangkwamunhwa 23 (March 2004): 63-90.

23. Chŏng Okcha. Chosŏnhugi chosŏnjunghwa sasang yŏn'gu. [Studies on the Chosŏn-centered Civilization Discourse in Late Chosŏn] Seoul: Ilchisa, 1998.

24. Chung, Edward Y.J.. The Korean Neo-Confucianism of Yi T'oegye and Yi Yulgok: A Reappraisal of the "Four-Seven Thesis" and Its Practical Implications for Self-Cultivation. New York: State University of New York Press, 1995.

25. Haboush, JaHyun Kim. "Constructing the Center: The Ritual Controversy and the Search for a New Identity in Seventeenth-Century Korea," in Culture and the State in Late Chosŏn Korea. eds. JaHyun Kim Haboush and Martina Deuchler, 46-90. Cambridge, MA: Harvard University Asian Center, 1999.

26. . "Contesting Chinese Time, Nationalizing Temporal Space: Temporal Inscription in Late Chosŏn Korea" in Time, Temporality, and Imperial Transition: East Asia from Ming to The Qing, ed. Lynn A. Struve, 115-141. Honolulu, HI: University of Hawaii Press, 2005.

27. Hong Chŏng'gŭn. "Namdang Han Wŏnjin ŭi mibalsim samch'ŭnggujo koch'al.” [An Inquiry into Namdang Han Won-jin's threefold dimensional mind-and-heart of Non-issuance] Han'guk sasangsahak 21 (December 2003): 417-445.

28. Kim Ch'angsu. "19segi huban, chibang chisigin ŭi taewaeinsik chihyŏng-Hwasŏhakp'a ŭi hwaigwan kwa ch’ŏng insik ŭl chungsim ŭro-." [Topology of international perception of local intellectuals in the late 19th century Joseon-Hwaseo School's perception of Sinocentrism and Qing-] Han'guksahakppo 72 (August 2018): 85-117.

29. Kim Chunsŏk. Chosŏnhugi chŏngch'isasangsa yŏn'gu. [The theory of national reconstruciton appeard in the late Choson dynasty] Seoul: 
Chisiksanŏpsa, 2003.

30. Kim T'aeyŏng. "Chujahak segyegwan kwa chosŏnsŏngnihag ŭi chuch'eǔisik." [World view of Jujahak and self reliant consciousness of Chosun Sungrihak] Taedongmunhwayŏn'gu 37 (December 2000): 5-71.

31. Kim Ho. "Chosŏnhugi hwairon chaego." [Rethinking the Hwa'ih-ron (華夷論) theory: examination of the 'chunchu agenda outside the region' (域外春秋) argument] Han'guksayŏn'gu 162 (September 2013): 123-163.

32. Lee, Joseph Jeong-il. "Patterning a Chosŏn-focused Discourse in Yi I's Understanding of Li." Journal of Asian History 46.1 (August 2012): $37-57$

33. _ "Use of Neo-Confucian term for universalism and Practice in Seventeenth-Century Chosŏn Korea." Archiv orientální 84.1 (January 2016): 159-187.

34. Lee Kyu-chul. “Chosŏn sŏngjongdae myŏng ŭi ch'ulbyŏng yoch’ŏng kwa taemyŏng'ŭisik pyŏnhwa." [Request for dispatch of the Joseon's armies during the rule of king Seongjong and any change in attitude toward the Ming dynasty] Han'guksayŏn'gu 169 (June 2015): 105131.

35. Ŏm Yŏnsŏk. "T'oegye ŭi sadanch'ilchŏng kwa kongsa ŭi munje." [T'oegye's Four-Seven Theory and the Concept of the Public and the Private] T'oegyehakpo 115 (June 2004): 45-92.

36. Ooms, Herman. "Human Nature: Singular (China) and Plural (Japan)?" in Rethinking Confucianism: Past and Present In China, Japan, Korea, And Vietnam. eds. Benjamin A. Elman, John B. Duncan, and Herman Ooms, 95-115. Los Angeles, CA: Asian Institute, 2002.

37. Tillman, Hoyt C. Confucian Discourse and Chu Hsi's Ascendancy. Honolulu: University of Hawaii Press, 1992.

38. Tu Wei-ming. Way, Learning, and Politics: Essays on the Confucian Intellectual. NY: State University of New York Press, 1993.

39. Xing Liju and Lin Xi. "Namdang's Theory on the Natures of Humans and Non-Human Living Beings and His Development of Zhu Xi's 
Theories.” Acta Koreana 19.2 (December 2016): 217-237.

40. Yi Ch'ŏnsŭng. "Yulgok it'onggiguksŏl kwa horaknonbyŏn e kkich'in yŏnghyang," [The Theory of Li-through and Ch'i-within and its influence on Ho-Rak debates] Han'guk sasangsahak 25 (December 2005):39-69.

41. ___ 'Nong'am Kim Ch'anghyŏp ŭi sasang kwa nakhak ŭro ŭi yŏnghyang." [The Thought of Nong Am, Kim, Chang-hyub and its Influence on Nak-Hak] Chosŏnsidaesahakppo 29 (June 2004): 137160.

42. Yi Tuch'an. "Yulgok sugiron ŭi sahoech'ŏlhakchŏk ŭimi." [The Significane of Hsiu-Chi (修己) in the Social Philosophy of Yulgok] Han'guksasangsahak 24 (June 2005): 313-343. 
$<$ Abstract $>$

\section{Engaging Differences in Chosŏn Korea: A Post-Ming Context}

Jeong-il Lee

The Chosŏn elites in the late seventeenth and the early eighteenth centuries phased Confucianism to their response to the rise of the Qing, whose Jurchen origins remained savage and underdeveloped in their memory even after the fall of Ming in 1644. They started establishing an ideological frontline intent on rearming themselves in Confucianism and dichotomizing civilization and barbarity in an anti-Qing campaign. This double stance to the post-Ming change stood out in times of uncertainties as one form of security strategy. The Old Doctrine 老論 (Noron), commenced the debate on human nature (人性) and delved into how the substance of the Confucian term for Universal Pattern (理) could be differently manifested in the human mind and heart. The first group Horon (湖 論) emanated an outspoken voice for the human difference in kind so that separation and differentiation, pivotal to the theoretical armament of antiQing discourse, were elucidated. The second group Nangnon (洛論) argued for a human difference in degree so that balance and accommodation, indispensable to the execution of state affairs including diplomacy with the Qing, were articulated. Significantly, the two views empowered the Old Doctrine to channel the seemingly abstract concept of human nature into an intellectual practice to revalidate Chosŏn as a land of civilization after the bygone Ming. In this respect, the debate exempliflies how the elites used Confucianism to generate a competent image of Chosŏn, how a dialogue between thought and geopolitics paved the way for the construct of an ideological frontline against the Qing. and how it became 
a discourse of security during the turbulent Ming-Qing transition.

Keywords: Confucian civilization of Chosŏn 小中華, Confucian term for Universal Pattern 理, human nature 人性, Ming-Qing transition, Old Doctrine 老論, Qing Dominance 


\section{〈국문초록〉}

\section{노론의 이념 투쟁과 '다름의 담론' \\ - 명청 교체기를 중심으로 -}

이정일 (동북아역사재단)

본 논문은 조선후기 노론 내부의 호론과 낙론 사이에 벌어진 인성 논쟁을 '다름의 담론'이라는 측면에서 재해석한다. 최근 학계에서는 이 논쟁의 역사적 함의를 파악하기 위해서 보편에 대한 다양한 해석 시도 및 그 정치적 상관성에 주목해 오고 있다. 필자 는 이러한 방법론을 활용하되 17 세기 후반과 18 세기 초반의 문맥 속에서 상기 논쟁의 성격을 노론의 중앙 권력에 대한 인식 그리고 對청 인식이라는 국내외 정치 상황과의 연동 속에서 분석했다. 먼저, 호론의 경우 재상을 중심으로 배제를 강조하는 정국 운영 을 지지하고 청조에 대해서 적대적 자세를 견지했는데 이를 차이의 존재론적 의미, 즉 다름의 절대성을 부각시키려는 그들의 사유 체계와 맞물렸다고 보았다. 낙론의 경우 왕권을 중심으로 통합적 경세를 지향하고 청조의 장기 지배 가능성을 포함한 탄력적인 對청 전략을 구상했는데 이는 차이의 공존, 특히 다름의 상대성에 주목한 그들의 유연 한 사고력과 밀접하게 어우러졌다고 보았다. 그러나 호론과 낙론의 인식론적 분기를 反청과 親청 등 이분법적 틀로 제한하기 보다는 노론의 이데올로기적 패권이라는 보다 큰 구도 속에서 이해할 필요가 있다. 왜냐하면 비록 상반된 방식으로 다름을 설명하더 라도 양자 모두 청의 중원 지배에 흔들리지 않는 문명국 조선의 자존감을 재확인하면 서 ⿶ㅣㅇ청ㅇ 인식의 폭을 확장시킬 수 있었기 때문이다. 달리 말하자면, 병자호란 이후 국 내외 정치적 도전에 대한 타개책을 모색한 노론이 절대적 다름과 상대적 다름을 병용 할 수 있는 보다 신축적인 이념 기제를 마련하는데 있어 호론과 낙론의 상반된 견해는 상보적인 역할을 한 것이라고 할 수 있다. 이러한 접근은 명청 교체기 노론 내부에서 전개된 '다름의 담론' 창출이 갖는 당대적 (當代的) 의미를 통해서 조선후기 사상사의 특징인 사상과 현실의 상호작용(성)을 보다 입체적으로 파악하는데 일조할 것으로 생 각된다.

주제어: 노론, 명청 교체기, 보편, 소중화, 인성, 이데올로기 